\title{
Investigation of the Relationship Between Separation Anxiety, Marital Adjustment and Life Satisfaction in Married Women
}

\author{
Evli Kadınlarda Ayrılık Anksiyetesi, Evlilik Uyumu ve Yaşam \\ Doyumu Arasındaki İlişkisinin İncelenmesi
}

\author{
Kahraman Güler ${ }^{1}$
}

\begin{abstract}
:
The aim of the study is to examine the relationship between separation anxiety and marital adjustment and life satisfaction in married women. This study was applied based on the relational screening model. Selection of sample was made with type of simple-random sample selection The population of the research consists of married couples between the ages of 23-63 living in various provinces.. The sample of the study consists of 200 married individuals between the ages of 23-63 living in Istanbul. Participants were randomly selected from various provinces. The scales used in the study are the Marriage Adjustment Scale, the Adult Separation Anxiety Inventory and the Diener Life Satisfaction Scale. A moderate and positive significant correlation was found between the total score of the Marriage Adjustment Scale and the score of the Diener Life Satisfaction Scale $(r=$ $.378, \mathrm{p}<.01$ ). A weak and negatively significant correlation was found between the total score of the Separation Anxiety Scale in adults and the score of the Diener Life Satisfaction Scale $(r=-.214, p<.01)$. A weak and negatively significant relationship was found between the total score of the Adult Separation Anxiety Scale and the Marriage Adjustment Scale $(\mathrm{r}=-.289, \mathrm{p}<.01)$.
\end{abstract}

Keywords: Separation Anxiety, Life Satisfaction, Marital Adjustment

${ }^{1} \mathrm{PhD}$, İstanbul Aydın University, Department of Psychology, İstanbul, Türkiye, kahramanguler@aydin.edu.tr Orcid; 00000002-0049-0658.

Address of Correspondence/Yazışma Adresi: Kahraman Güler, İstanbul Aydın University, Department of Psychology, İstanbul, Türkiye, E-mail: kahramanguler@aydin.edu.tr

Date of Received/Geliş Tarihi: 08.09.2021, Date of Revision/Düzeltme Tarihi: 23.09.2021, Date of Acceptance/Kabul Tarihi: 06.10.2021, Date of Online Publication/Çevirimiçi Yayın Tarihi: 01.12.2021

Citing/Referans Gösterimi: Güler, K. (2021). Investigation of the Relationship between Separation Anxiety, Marital Adjustment and Life Satisfaction in Married Women, Cyprus Turkish Journal of Psychiatry \& Psychology, 3(4): 272-278

(C) 2021 The Author(s). Published by Cyprus Mental Health Institute / Cyprus Turkish Journal of Psychiatry and Psychology (www.ktppdergisi.com). This article is an open access article distributed under the terms and conditions of the Creative Commons Attribution 4.0 license which permits use, sharing, adaptation, distribution and reproduction in any medium or format, provided the original work is properly cited and is not used for commercial purposes. http://creativecommons.org/licenses/by/4.0/ 


\section{Öz:}

$\mathrm{Bu}$ araştırmada evli olan kadınlarda ayrılık anksiyetesi ile evlilik uyumu ve yaşam doyumu arasındaki ilişkinin incelenmesi amaçlanmaktadır. Araştırma ilişkisel tarama modeli baz alınarak uygulanmıştır. Örneklem seçimi basit-rastgele örneklem seçim türü kullanılarak yapılmıştır. Araştırmanın evrenini çeşitli illerde yaşayan 23-63 yaş arası evli çiftler oluşturmaktadır. Araştırmanın örneklemini ise İstanbul'da yaşayan 23-63 yaş arası 200 evli birey oluşturmaktadır. Katılımcıların hepsi çeşitli illerden rastgele bir şekilde seçilmiştir. Araştırmada kullanılan ölçekler arasında sırasıyla Evlilik Uyum Ölçeği, Yetişkin Ayrılık Anksiyetesi Envanteri ve Diener Yaşam Doyum Ölçeği bulunmaktadır. Evlilikte Uyum Ölçeği ile Diener Yaşam Doyum Ölçeği puanlarında orta seviyede ve pozitif yönde ilintili bulunmuştur $(r=.378, p<.01)$. Yetişkinlerde Ayrılık Anksiyetesi Ölçeği toplam puanı ile Diener Yaşam Doyum Ölçeği puanı arasında zayıf ve negatif olarak ilintili bulunmuştur $(r=-.214$, $\mathrm{p}<.01$ ). Yetişkinlerde Ayrılık Anksiyetesi Ölçeği puanı ile Evlilikte Uyum Ölçeği puanlarında zayıf düzeyde ve negatif olarak ilintili bulunmuştur $(\mathrm{r}=-.289, \mathrm{p}<.01)$.

Anahtar Kelimeler: Ayrılık Anksiyetesi, Yaşam Doyumu, Evlilik Uyumu

\section{Giriş}

Evlilik cinsel güdüyü doyurma açısından biyolojik bir ihtiyac1, birlikte güven, korunma, dayanışma içinde olduklarını hissetmek sosyal ihtiyacı, psikolojik açıdan da bakıldığında bağ kurmak, sevmek ve sevilmek gibi ihtiyaçları karşılama işlevi görür (Özgüven, 1997). Evlilik uyumunu kavramı bu ihtiyaçların ne miktarda karşılandığını açıklamaya yarar. Bireyin hayatında gelişen en önemli kişilerarası ilişkilerden biri olarak kabul edilen evlilik birçok birey için önemli bir doyum ve mutluluk kaynağı iken, başkaları açısından birç ok olumsuz yaşantıyı da getiren bir olgu olarak da kabul edilir. Bu çalışmada evlilik uyumunu etkileyen önemli, faktörlerden biri olan yetişkin ayrıllk anksiyetesine vurgu yapılmıştır. Kadının toplumsal yaşamdaki statüsü, sosyal hayattaki gücü, stres verici yaşam olaylarının çok oluşu ve dayatılan fazla roller, toplumsal cinsiyet rolleri ve kadınlar üzerindeki farklı politikalar kadınların daha fazla sorumluluk altında olmasina ve daha fazla ruhsal anlamda zorluk yaşamasına neden olur (Nolen-Hoeksema ve ark., 1999; Yaşar, 2007). Evli kadınlarda ayrilık anksiyetesi ile evlilik uyumu (Solmuş, 2003) ve yaşam doyumu (Tekin, 2019) arasında anlamlı bir ilişkinin olduğu düşünülmektedir. Ayrılık anksiyetesi, çocuğun evinden veya evinde bağlanmış olduğu kişiden ayrılması sonucunda beklenenden fazla ve tekrarlayıcı anksiyete duyması şeklinde açıklanmaktadır. Ayrılık anksiyetesi oluşumunda çevresel faktörler ve ebeveyn tutumları rol oynamaktadır. Ayrılık anksiyesinin kişinin hem kendisini hem diğerlerini olumlu algısı doğrudan ilişkisi olan güvenli bağlanmayla yakından ilişkisi mevcuttur. Güvensiz bağlanma stili geliştiren bireyler ayrılmakta zorluk yaşarlar (Jurbergs ve Deborah, 2005). Ayrılma anksiyetesinin uzun süre devam etmesi ve işlevselliği sekteye uğratması durumunda ancak bir ruhsal bozukluğa dönüştüğü kabul edilebilir (Köroğlu, 1995). Annenin çocuğa karşı tutumu ve disiplin etme amaçlı terk etme, yalnız bırakma tehditleri, korkutucu hikayelerin çocuk üzerinde ayrılık kaygısının ilerlemesine ya da mevcut olan ayrılık kaygısını tetikler. $\mathrm{Bu}$ durum yetişkinler içinde geçerlidir. Anksiyeteli yetişkinler, aşırı derecede bağımlı hale gelmekte ve eşlerden yüksek seviyede yakınlık, onay ve yanıt istemektedir. Eşlerine güvensiz olma eğilimindedirler ve kendilerini değersiz görürler, daha az samimiyet isterler, duygularını bastırırlar (Kim ve ark., 1991; Rober ve ark., 2008). Bu sebepten ayrılık anksiyetesi yüksek yetişkinlerin evlilik ve yaşam doyumu düzeylerinin olumsuz yönde etkileneceği düşünülebilir. Ebeveyne, arkadaş ve partnere bağlanma ile yaşam doyumu arasındaki ilişkiyi inceleyen bir çalışmadan elde edilen bulgu sonuçları anne-baba ve arkadaşa bağlanma ile yaşam doyumu arasında anlaml, pozitif korelasyonun olduğunu, romantik bağlanmanın ise yüksek düzeyde etkisi olduğu bulunmuştur (Guarnieri ve ark., 2015). Yaşam doyumu bireylerin yaşantılarını ve yaşantılarının birçok boyutunu içermektedir. Yaşam doyumu kavramının belli durumlara değil, tüm hayat yaşantısına yönelik olduğu da bilinmektedir. Yaşam doyumu insanların hayat karşısında aldıkları memnuniyet ve ulaşmayı hedefledikleri memnuniyet düzeyi olarak tanımlanmaktadır. Yaşam doyumunu ve düzeyini etkileyen birçok faktör olduğu bilinmektedir. Evlilik uyumu, yaş, iş durumu, medeni durum, ekonomik gelir bu faktörlerden bazılarıdır (Özer ve Karabulut, 2003). Yaşam doyumu aynı zaman da evlilik yaşantısını ve uyumunu etkileyen ayrica bunlardan etkilenen bir kavram olarak bilinmektedir. Evliliğin bireylerin yaşantılarında önemli bir konumda olmasına rağmen evlilik niteliğinin yaşam doyum ve kalitesiyle bağlantılı olduğunu ortaya koyan çalışmalar bulunmaktadır (Hünler ve Gençöz, 2003). Evlilik uyumu ise iki birey arasında gerçekleşen ilişki ile, bireylerin günlük hayat yaşantılarını ve psikolojik ruh hallerini etkileyen bir kavram olarak tanımlanmaktadır. Evlilikte uyumu sağlayabilen bireyler, kendilerini evlilik ve günlük yaşantılarında mutlu hissetmektedirler. Spanier ise 1976 yılında evlilik uyumu kavramını çiftlerin günlük rutin yaşantılarında ve hayatlarında farklılık gösteren şart ve koşullara uyum sağlaması, memnun olması ve karşılıklı uyum içinde değişime uğranması olarak ifade etmektedir (Spanier ve Lewis, 1980). Evlilikteki uyum ile gerçekleşen bu mutluluk duygusu çiftlerin ruhsal sağlıklarını da olumlu yönde etkilemektedir (Akar ve ark., 2005). Literatür çalışmaları incelendiğinde evlilik uyumu ile ayrılma anksiyetesi arasında anlamlı bir ilişki olduğunu ortaya koyan çalışmalar olduğu görülmüştür (Lussier ve ark., 1997; Tutarel-Kışlak ve Çavuşoğlu, 2006). Evlilik doyumları ve yaşam doyumları değişkenlerini içeren bir araştırmada ikisinin arasında anlamlı düzeyde ilişki olduğu saptanmıştır (Yıldız ve Çevik, 2016). Alan yazın bağlamında evli kadınlarla yapılmış çalımların sayısının az olması ayrıca ayrılık anksiyetesi, evlilik uyumu ve 
yaşam doyumu arasındaki ilişkiyi inceleyen çalışmaların olmaması bu çalışmanın literatüre olan katkısını artıracaktır. Evlilik Türkiye toplumunda son derece önemsenen bir kurum ve evliliklerde ortaya çıkan sorunların saptanması evlilik uyumunu bozan faktörlerin ortaya konması açıdan önem arz etmektedir. Özellikle toplumsal cinsiyet rolleri bağlamında kadınlar daha dezavantajlı yetiştirilmektedir. Önemli ötekilerle kurulan bağların öneminin ortaya konması ve evlilik sorunlarının bireysel dinamiklerinin anlaşılması son derece önemlidir.

\section{Yöntem}

\section{Örneklem}

$\mathrm{Bu}$ araştırma ilişkisel tarama modeli baz alınarak uygulanmıştır. Örneklem seçimi basit-rastgele örneklem seçimi türü kullanılarak yapılmıştır. Araştırmanın evrenini çeşitli illerde yaşayan 23-63 yaş arası evli çiftler oluşturmaktadır. Araştırmanın örneklemini ise İstanbul'da yaşayan 23-63 yaş arası 200 evli birey oluşturmaktadır. Katılımcılar çeşitli ilçelerden tesadüfi olarak seçilmiştir.

\section{Veri Toplama Araçları}

\section{Evlilik Uyum Ölçeği (OBDÖ)}

Locke ve Wallace (1959) tarafından geliştirilmiş ve Kışlak (1996) tarafından Türkçeye uyarlanıp geçerlik ve güvenirlik çalışması yapılmıştır. Ölçeğin amacı evlilikten alınan doyum ve evlilikteki uyumu ölçmektir.

\section{Yetişkin Ayrılık Anksiyetesi Envanteri (BDE)}

Manicavasagar ve arkadaşları (2003) tarafindan geliştirilen Yetişkin Ayrılma Anksiyetesi Anketi (Adult Separation Anxiety Questionnaire, ASA), yetişkinlikteki ayrılık anksiyetesi semptomlarını kapsamaktadır. 27 maddeden oluşan ölçek öz bildirim ölçeği olarak ifade edilmektedir. 4'lü likert tipi olarak ölçüm yapan ölçekte, her madde 0 "hiç hissetmedim" ile 3 "çok sık hissettim" olarak değerlendirilmektedir (Manicavasagar ve ark., 2003; Diriöz ve ark., 2012).

\section{Diener Yaşam Doyum Ölçeği}

Diener, Laresen, Emmons ve Griff tarafindan geliştirilen, Köker tarafında Türkçe uyarlaması yapılan Yaşam Doyum Ölçeği yaşam doyumuyla ilişsili beş maddeden meydana gelmektedir (Diener ve ark.,1985).

\section{İşlem}

İstanbul Aydın Üniversitesi Etik Kurulundan onay alındıktan sonra çalışmaya başlanmıştır. Veriler, katılımcılardan pandemi dönemi koşullarından dolayı online olarak toplanmıştır. Instagram, Whatsapp, Facebook ve diğer dijital kitle iletişim araçları kullanılarak yaklaşık 2 aylık bir sürede toplanmıştır. Katılımcıların bilgilendirilmiş onam formunu onaylayarak çalışmaya katılmışlardır. Toplanılan veriler analiz edilerek değerlendirilmiştir.

\section{Bulgular}

Tablo 1: . Diener Yaşam Doyum Ölçeği, Evlilikte Uyum Ölçeği ve Yetişkinlerde Ayrllık Anksiyete Ölçeğinin Puanları Arasındaki İlişkiyi Belirlemek Üzere Yapılan Pearson Korelasyon Analizi Sonuçları

\begin{tabular}{|c|c|c|c|c|}
\hline & & $\begin{array}{l}\text { Diener Yaşam Doyum } \\
\text { Ölçeği }\end{array}$ & $\begin{array}{l}\text { Evlilikte Uyum } \\
\text { Ölçeği }\end{array}$ & $\begin{array}{l}\text { Yetişkinlerde Ayrılık } \\
\text { Anksiyetesi Ölçeği }\end{array}$ \\
\hline \multirow[t]{3}{*}{ Diener Yaşam Doyum Ölçeği } & $\mathrm{r}$ & 1 & & \\
\hline & $\mathrm{p}$ & & & \\
\hline & $\mathrm{N}$ & 200 & & \\
\hline \multirow[t]{3}{*}{ Evlilikte Uyum Ölçeği } & $\mathrm{r}$ &, $378^{* *}$ & 1 & \\
\hline & $\mathrm{p}$ & 0,000 & & \\
\hline & $\mathrm{N}$ & 200 & 200 & \\
\hline \multirow{3}{*}{$\begin{array}{l}\text { Yetişkinlerde Ayrılık } \\
\text { Anksiyetesi Ölçeği }\end{array}$} & $\bar{r}$ &,$- 214^{* *}$ &,$- 289^{* *}$ & 1 \\
\hline & $\mathrm{p}$ & 0,002 & 0,000 & \\
\hline & $\mathrm{N}$ & 200 & 200 & 200 \\
\hline
\end{tabular}

Evlilikte Uyum Ölçeği toplam puanı ile Diener Yaşam Doyum Ölçeği puanı arasında orta düzeyde ve pozitif yönde anlamlı ilişki bulunmuştur $(\mathrm{r}=.378, \mathrm{p}<.01)$.

Yetişkinlerde Ayrılık Anksiyetesi Ölçeği toplam puanı ile Diener Yaşam Doyum Ölçeği puanı arasında zayıf düzeyde ve negatif yönde anlamlı ilişki bulunmuştur ( $\mathrm{r}=$ $.214, \mathrm{p}<.01)$.

Yetişkinlerde Ayrılık Anksiyetesi Ölçeği toplam puanı ile Evlilikte Uyum Ölçeği puanı arasında zayıf düzeyde ve negatif yönde anlamlı ilişki bulunmuştur $(\mathrm{r}=-.289, \mathrm{p}<.01)$. 
Tablo 2: Evlilikte Uyum ve Ayrılık Anksiyetesinin Yaşam Doyumuna Etkisi

\begin{tabular}{lllllllll}
\hline & \multicolumn{3}{c}{ Standart } & & & & & \\
& B & Hata & Beta & t & p & R2 & F & P \\
\hline (Sabit) & 13,980 & 3,695 & & 3,784 & 0,000 & 0,155 & 18,071 & 0,000 \\
Evlilikte Uyum & 0,254 & 0,050 & 0,345 & 5,046 & 0,000 & & & \\
Ölçeği & & & & & & & & \\
Yetişkinlerde & $-0,078$ & 0,047 & $-0,114$ & $-1,671$ & 0,096 & & & \\
Ayrılık & & & & & & & & \\
$\begin{array}{l}\text { Anksiyetesi } \\
\text { Ölçeği }\end{array}$ & & & & & & & & \\
\hline
\end{tabular}

Tabloda görüldüğü üzere evlilikte uyum ve yetișkinlerde ayrılık anksiyetesi yaşam doyumunu anlamlı düzeyde yordadığ1 görülmektedir( $\mathrm{R} 2=.155, \mathrm{p}<.0 .01)$.Ad1 geçen değişkenler birlikte yaşam doyumundaki toplam varyansın yaklaşık \%16'sını açıklamaktadır. Beta katsayısına göre etki gücünün sırası. Evlilikte uyum,
Ayrılık anksiyetesi șeklindedir Regresyon katsayılarının anlamlılı̆̆ına ilişkin $\mathrm{t}$ - testi sonuçları incelendiğinde ise evlilikte uyum yaşam doyumu için anlamlı bir yordayıcı olduğu görülmektedir. Diğer değişkenin anlamlı bir etkisi yoktur.

Tablo 3: Örneklemin Yaş Değişkenine Göre Evlilikte Uyum Ölçeği Puanları Arasındaki Farkın Anlamlılığını Test Etmek İçin Yapılan Tek Yönlü Varyans Analizi (ANOVA) Sonuçları

\begin{tabular}{|c|c|c|c|c|c|c|c|c|c|}
\hline & $\mathbf{N}$ & $\overline{\overline{\mathbf{X}}}$ & S. & & K.T & Sd. & K.O & $\mathbf{F}$ & $\mathbf{p}$ \\
\hline $20-25$ & 47 & 40,23 & 13,18 & G.Aras1 & 2116,562 & 3 & 705,521 & 5,046 & 0,002 \\
\hline 26-30 & 56 & 43,43 & 9,06 & G.İçi & 27405,393 & 196 & 139,823 & & \\
\hline 31-35 & 32 & 40,22 & 9,48 & Toplam & 29521,955 & 199 & & & \\
\hline 35 yaş üstü & 65 & 35,18 & 13,76 & & & & & & \\
\hline Toplam & 200 & 39,49 & 12,18 & & & & & & \\
\hline
\end{tabular}

Örneklem grubun yaş değişkenine göre Evlilikte Uyum Ölçeğinin anlamlı farklılık bulunmaktadır [F=5.046, $\mathrm{p}<.01]$.Post Hocçoklu karşılaştırma tekniğinin kullanılacağına karar vermek için öncelikle Levene's testi ile grup dağılımlarının varyanslarının homojen olduğu saptanmıştır(p=.177).Yapılan Scheffe testi sonucunda 2025 yaş arası olan grup 35 yaş üstü olan grup arasında 20-
25 yaş arası olan grup daha fazla puan aldığından istatistiksel olarak anlaml 1 fark bulunmuştur( $\mathrm{p}<.05)$.Yapılan Scheffe testi sonucunda 2630 yaş arası olan grup 35 yaş üstü olan grup arasında 2630 yaş arası olan grup daha fazla puan aldığından istatistiksel olarak anlamlı fark bulunmuştur $(\mathrm{p}<.05)$

Tablo 4: Örneklemin Gelir Durumu Değişkenine Göre Evlilikte Uyum Ölçeği Puanları Arasındaki Farkın Anlamlılı̆̆ını Test Etmek İçin Yapılan Tek Yönlü Varyans Analizi (ANOVA)

\begin{tabular}{|c|c|c|c|c|c|c|c|c|c|}
\hline & $\mathbf{N}$ & $\overline{\mathbf{X}}$ & S. & & K.T & Sd. & K.O & F & $\mathbf{p}$ \\
\hline Kötü & 7 & 31,57 & 10,28 & G.Aras1 & 1158,315 & 2 & 579,157 & 4,023 & 0,019 \\
\hline Orta & 172 & 39,10 & 12,01 & G.İçi & 28363,640 & 197 & 143,978 & & \\
\hline Yüksek & 21 & 45,24 & 12,37 & Toplam & 29521,955 & 199 & & & \\
\hline Toplam & 200 & 39,49 & 12,18 & & & & & & \\
\hline
\end{tabular}

Örneklem grubun gelir durumu değişkenine göre Evlilikte Uyum Ölçeği anlamlı farklılık bulunmaktadır [F=4.023, $\mathrm{p}<.05]$.Post Hocçoklu karşılaştırma tekniğinin kullanılacağına karar vermek için öncelikle Levene's testi ile grup dağılımlarının varyanslarının homojen olduğu saptanmıştır $(p=.771)$.Yapılan Scheffe testi sonucunda geliri yüksek olan grup ile geliri orta olan grup arasında 
geliri yüksek olan grup daha fazla puan aldığından istatistiksel olarak anlamlı fark bulunmuştur( $\mathrm{p}<.05)$. Geliri yüksek olan grup ile geliri düşük olan grup arasında geliri yüksek olan grup daha fazla puan aldığından istatistiksel olarak anlamlı fark bulunmuştur $(\mathrm{p}<.05)$.

\section{Tartıșma}

$\mathrm{Bu}$ bölümünde araştırmada amaçlanan ana hedefe ulaşmak için yanıt aranan araştırma sorularına uygun şekilde yapılmış olan analizlerden elde edilen sonuçlar, ilgili yazın çerçevesinde tartışılmaktadır.

Araştırmamızın sonuçlarına göre evlilik uyumundan alınan puan yükseldikçe yaşam doyumu; yaşam doyumundan alınan puan yükseldikçe evlilik doyumu da yükselecektir. Evlilik doyumları ve yaşam doyumları değişkenlerini içeren bir araştırmada ikisinin arasında anlamlı düzeyde ilişki olduğu saptanmıştır (Yıldız ve Çevik, 2016). Kişinin özel hayatındaki mutluluğu da evlilik hayatını olumlu etkilemektedir. Yaşam doyumu ve evlilik uyumu ile ilgili yapılan araştırmalar incelendiğinde kişinin yaşamından beklentileri ve beklentilerini karşılayabilmesiyle beraber partnerini daha iyi anlayabilmekte ve aralarındaki ilişki doyumu da olumlu yönde etkilenmektedir. Yapılan bir çalışmada evlilik yaşam doyumu psikolojik iyi oluş üzerinde kayda değer bir anlama sahiptir (Özbek, 2016). Evliliği etkileyen birçok faktör bulunmaktadır. Bu faktörlerin en önemlilerden birinin de yaşam doyumu olduğu bilinmektedir. Bireylerin yaşam standartlarının karşılanmasıyla beraber artan yaşam doyumu kişinin gerek ilişkilerinde gerek sosyal çevresindeki ilişkilerini olumlu olarak etkilemektedir. Günümüz yaşam koşullarına ayak uydurmak zorlaşmaktadır. Kişi bu koşul ve standartlara uyum sağlayamadığın da tükenmişlik yaşayabilmekte ve bu durum evliliğini olumsuz etkileyebilmektedir (Tekin, 2019).

Literatür çalışmaları incelendiğinde; Çelik ve Tümkaya öğretmenlerin evlilik uyumlarının psikolojik iyi olma ve bazı değişkenler açısından incelemiş ve iki değişken arasında pozitif yönde anlamlı bir korelasyonun olduğu sonucunu elde etmişlerdir (Çelik ve Tümkaya, 2012). İncelenen araştırmalar Evlilik uyumu ile yaşam doyum arasında anlamlı bir farklılık vardır hipotezini destekler niteliktedir.

Araştırmamıza göre evlilik uyumu ile yetişkin ayrılık anksiyetesi arasında anlaml bir farklılık vardır. $\mathrm{Bu}$ bulgunun temel sebepleri olarak bireylerin ayrılık kaygis1 gütmeden ilişkilerini devam ettirmelerinin (Owen ve ark., 2011), ve olumsuz mitlere sahip olmamalarının (Popenoe, 2002) sosyal ilişkilerini güçlendirdiği ve bu durumunda evlilik uyumu da arttırması söylenebilmektedir. Literatür çalışmaları incelendiğinde Selçuk'un yapmış olduğu araştırma bulgularına yetişkin ayrılma anksiyetesi ile evlilik uyumu arasındaki ilişki incelendiğinde ayrılma anksiyetesi yaşamayan güvenli bağlanan bireyler onaylanmama, ayrılma ya da diğer insanları memnun etme kaygısı bulunmadığından bu bireylerin uyum düzeylerinin ve evlilik uyumlarının yüksek olduğu görülmüştür. Bireylerin sürekli onaylanma ya da ayrılmama için kendilerini baskı altında hissetmeleri bu bireylerin kendilerini rahat hissetmemelerine ve huzursuzluk yaşayarak evlilik uyumlarının azalmasına sebep olmaktadır (Selçuk ve ark., 2005). BoğdaKantarcı'nın yapmış olduğu araştırma sonuçlarına göre ayrilık kaygısı olmayan bireylerin çatışma ve problem çözme becerilerini daha aktif kullandıkları ve eşleri ile olan sorunlarını daha iyi çözebilmeleri sebebi ile evlilik uyumlarının yüksek olduğu saptanmaktadır (Kantarcı ve Şendil, 2012). Vander Drift ve arkadaşlarının düşük bağlılık içeren evlilik dişı romantik ilişkiler yaşayan bireylerin terk etme davranışlarına yönelme sürecini inceledikleri araştırma bulguları ayrılma kaygısı ve bağlılığın evlilik uyumunu olumsuz etkilediğini ortaya koymaktadır (Drift ve ark., 2009). Literatür çalışmaları incelendiğinde evlilik uyumu ile ayrılma anksiyetesi arasında anlamlı bir ilişki olduğunu ortaya koyan çalışmalar olduğu görülmüştür (Lussier ve ark., 1997; Solmuş, 2003; Tutarel-Kışlak ve Çavuşoğlu, 2006). Araştırmamıza göre Yaşam Doyumu ile yetişkin ayrılık anksiyetesi arasında anlamlı bir farklılık vardır. Literatür çalışmaları incelendiğinde; Hwang ve arkadaşlarının yapmış oldukları araştırma bulguları ayrılma anksiyetesi yaşayan bireylerin yaşam doyumlarının düşük olduğunu saptamaktadir (Hwang ve ark., 2009). Kermen ve Sarı'nın Üniversite öğrencilerinde ihtiyaç doyumu ve öznel iyi oluş arasındaki ilişkini inceledikleri araştırma bulguları güvenli bağlanması olmayan ayrılma anksiyetesi yaşayan bireylerde yaşam doyumunun düşük olduğunu saptamaktadır (Kermen ve ark., 2014). İlhan ve Özbay'ın yaşam amaçlarının ve psikolojik ihtiyaç doyumunun öznel iyi oluş üzerindeki yordayıcı rolünü araştırdıkları araştırma bulguları da yaşam doyumu ile kaygılı bağlanması olan, ayrılma kaygisı yaşayan bireylerin yaşam doyumlarının düşük olduğu sonucunu elde etmiştir (İlhan ve Özbay, 2010). Yetişkin ayrılma anksiyetesi arttıç̧a yaşam doyum düzeyinde azalma meydana gelmektedir. Birçok araştırma bu sonuç ile aynı bulgular elde etmiştir (Shahyad ve ark., 2011; Chen ve ark., 2017). Güvenli bağlanma tarzını benimseyen bireylerin bireysel iyilik durumları, ilişki kaliteleri ve yaşam doyumları yüksek olduğu görülürken, güvensiz bağlanan, yetişkin ayrılma anksiyetesi bulunan bireylerin ise iyilik durumları, ilişki kaliteleri ve yaşam doyumlarının düşük olduğu saptanmaktadır. Lavy ve Littmann ile Ovadi'nin yapmış oldukları çalışma bulguları yetişkin ayrılma anksiyetesi ve yaşam doyumu ile ilintili olduğunu ortaya koymaktadır (Lavy ve ark.,2011; Leak ve Cooney, 2001).

Araştırmamızdan çıkan sonuçlara göre gelirin artmasıyla birlikte evlilik uyumunda da artışlar meydana gelmektedir. Günümüz yaşam koşullarında yüksek standartlara sahip olmak kişinin üretkenliği ve bireysel yaşam doyumu açısından olumlu bir faktör olarak görülmektedir. Yüksek gelire sahip olan ve yüksek standartlarda yaşamını sürdüren eşlerin evliliklerindeki uyumda da artışlar meydana gelmektedir. Evliliğin başlangicında olan ve devam eden ya da evlendikten sonra borç ya da iflas sonucu ekonomik sıkıntı yaşayan kişilerin, bireysel olarak doyumları azalmakta ve tükenmişliği ortaya çıkarmaktadır. Olumsuz yaşam koşulları bireysel olarak kişileri etkilemekle beraber eşler arasındaki iletişimi de engellemektedir ve evlilik uyumu da bu durumdan olumsuz olarak etkilenmektedir (Broderick ve Daniel , 1986). Yalçın'ın yapmış olduğu araştırma sonucu aylık gelirin evlilik uyum düzeyini farklılaştırdığını destekler niteliktedir (Yalçın, 2014). Şener' in yapmış olduğu araştırma da erkek ve kadınların maddi gelirlerinin artmasıyla beraber evlilik doyumunun 
da arttığ bulguları elde edilmiştir (Şener ve Terzioğlu, 2002). İncelenen araştırmalar Evlilik Uyumu ve gelir durumu değişkenleri arasında manidar bir başkalık vardır varsayımını pekiştiren niteliktedir.

Araştırmamıza göre evlilik uyumu ve yaş değişkeni arasında manidar bir fark vardır. Buna göre yaş düzeyi arttıkça evlilik uyumu artmakta yaş düzeyi azaldıkça evlilik uyumu azalmaktadır. Yapılan literatür çalıșmaları incelendiğinde;

Both ve wiht'in yapmış olduğu çalışma sonucuna göre genç yaşta evlilik gerçekleştiren bireylerin evlilik uyumları daha düşük olduğu görülmüştür. Elde edilen bulgu sonuçları yaş ile evlilik uyumu arasında anlamlı bir ilişki olduğunu göstermektedir (Booth ve Lynn , 1980). Carter ve Glick'in yapmış oldukları araștırmamızın sonuçlarına göre yaş ve evlilik uyumu arasında manidar bir fark olduğu bulunmuştur (Carter ve Paul , 1970). İncelenen araştırmalar evlilik uyumu ve yaş değişkeni arasında manidar bir fark bulunmaktadır varsayımını pekiştirmektedir.

Hamamcı'nın yapmış olduğu araştırma sonucuna göre yaş, çocuk sayısı, eğitim seviyesi ve cinsiyet ile yaşam doyumu ile manidar bir ilintiye rastlanmamıştır (Hamamcı, 2005). Kendi araştırmamızda bu verileri teyit edememişizdir.

\section{Öneri}

Elde edilen bulgular literatür ışı̆̆ında değerlendirildiğinde kadın toplumsal yaşamın devamlılığı ve ilişkilerin daha iyi yaşanılabilir olması kilit konumdadır bu bağlamda kadının nasıl yetiştirildiği son derece önemlidir. Sorunun daha sağlıklı çözümlere kavuşabilmesi için öncelikle cinsiyet eşitlikçi yetiştirme tarzı temek insan hakları çerçevesinde yapılmalı ve evlilik kadının sorumluluğunda algısı değiştirilmelidir. Ancak insan ruhsal dünyası çeşitli faktörlerden etkilenmektedir. Yetişkin ayrılık anksiyetesi olan kadınların ilişkilerinde daha fazla doyum alabilmesi için çocuk ve ergenlik yaşantılarının bunda önemli pay sahibi olduğunu ve ruhsal zorlanmanın farklı modellerde tedavi edilebildiğini ortaya koyan birçok çalıșmanın mevcut olduğundan yola çıkarak değerlendirmelidir. Evlilik uyumunun daha sağlıklı bireylerle olmakla yükselebileceği unutulmamalıdır. Örneklem grupları değiştirilerek bu çalışma tekrar yürütülebilir. Ruh sağlığ uzmanlarının erken dönem bağlanmanın önemini vurgulayan psikoterapi yaklaşımlarından faydalanması son derece önemli olacaktır.

\section{Beyannameler}

Etik Onay ve Katılma İzni

Uygulanamaz.

Yayın İzni

Uygulanamaz.

Veri ve Materyallerin Mevcudiyeti

Uygulanamaz.

Çıkar Çatışması

Yazarlar çıkar çatışması olmadığını beyan eder.

Finansman

Uygulanamaz.

\section{Yazar Katkıları}

SK, MEK, İE çalışmanın tasarımını oluşturmuştur. SK, IE veri toplama aşamasını yürütmüştür. SK verileri analiz etmiştir. SK, MEK, İE makalenin taslağını oluşturmuş ve kritik revizyonunu üstlenmiștir. SK çalışmanın teknik ve materyal desteğini sağlamıştır. Tüm yazarlar makalenin son halini okumuş ve onaylamıştır.

\section{Kaynaklar}

Aker, S., Şahin, M. K. ve Oğuz, G. (2019). Sexual myth beliefs and associated factors in university students. Turkish Journal of Family Medicine and Primary Care, 13(4), 472-480.

Antony, M. M., Purdon, C. L., Huta, V., \& Swinson, R. P. (1998). Dimensions of perfectionism across the anxiety disorders. Behaviour research and therapy, 36(12), 1143-1154.

Bardone-Cone, A. M., Wonderlich, S. A., Frost, R. O., Bulik, C. M., Mitchell, J. E., Uppala, S., \& Simonich, H. (2007). Perfectionism and eating disorders: Current status and future directions. Clinical Psychology Review, 27(3), 384-405.

Çelik, E. ve Arıcı, N. (2014). Evli bireylerin cinsel utangaçlığını etkileyen faktörlerin yapısal eşitlik modeli ile incelenmesi. Kuram ve Uygulamada Eğitim Bilimleri, 14(5), 1689-1707.

Demirci, E., Çepikkurt, F., Kale, E. K. ve Güler, E. (2018). Öğretmen adaylarının mükemmeliyetçilik ve öfke eğilimleri arasındaki ilișkinin incelenmesi. Beden Eğitimi ve Spor Bilimleri Dergisi, 20(1), 106-121.

Ejder-Apay, S., Özorhan, E. Y., Arslan, S., Özkan, H., Koc, E. ve Özbey, I. (2015). The sexual beliefs of Turkish men: comparing the beliefs of men with and without erectile dysfunction. Journal of Sex \& Marital Therapy, 41(6), 661-671.

Erdoğan, Ç. H., Topuz, R. ve Bahadır, Z. (2018). Examination of football players' perfectionism features and subjective stress perceptions. Türk Spor ve Egzersiz Dergisi, 20(3), 283-291.
Eriş-Davul, Ö. ve Ertekin-Yazıcı, A. (2019). Üniversite yaşamının cinsel mit ve tutumlara etkisi. Cukurova Medical Journal, 44(4), 1432-1441.

Frost, R. O., Marten, P., Lahart, C., \& Rosenblate, R. (1990). The dimensions of perfectionism. Cognitive Therapy and Research, 14(5), 449-468.

Gölbaşı, Z., Evcili, F., Eroğlu, K. ve Bircan, H. (2016). Sexual myths scale (SMS): development, validity and reliability in Turkey. Sexuality and Disability, 34(1), 75-87.

Gönülateş, S. ve İmamoğlu, O. (2019). Tenisçilerde cinsiyet ve eğitim durumuna göre mükemmeliyetçilik. 2. Uluslararası Herkes için Spor ve Wellness Kongresi, Antalya.

Greenspon, T. S. (2000). "Healthy perfectionism" is an oxymoron!: Reflections on the psychology of perfectionism and the sociology of science. Journal of Secondary Gifted Education, 11(4), 197-208.

Güdül-Öz, H., Ak-Sözer, G. ve Balc1-Yangın, H. (2020). Hemşirelik öğrencilerinin cinsel mitlere inanma durumları ve etkileyen faktörler. Ordu Üniversitesi Hemşirelik Çalışmaları Dergisi, 3(2), 136-145.

Güneş, M., Akçal, H., Dede, O., Okan, A., Bulut, M., Demir, S., ... ve Sır, A. (2016). Prematür ejakülasyon olgularında cinsel mitlere inanma düzeyi. Dicle Tip Dergisi, 43(2), 319-328.

Hart, B. A., Gilner, F. H., Handal, P. J., \& Gfeller, J. D. (1998). The relationship between perfectionism and self-efficacy. Personality and Individual Differences, 24(1), 109-113. 
Hartmann, U., Philippsohn, S., Heiser, K., \& Rüffer-Hesse, C. (2004). Low sexual desire in midlife and older women: personality factors, psychosocial development, present sexuality. Menopause, 11(6), 726-740.

Hewitt, P. L., \& Flett, G. L. (1991). Perfectionism in the self and social contexts: conceptualization, assessment, and association with psychopathology. Journal of Personality and Social Psychology, 60(3), 456.

Hewitt, P. L., Flett, G. L., \& Turnbull- Donovan, W. (1992). Perfectionism and suicide potential. British Journal of Clinical Psychology, 31(2), 181-190.

Hibbard, D. R., \& Davies, K. L. (2011). Perfectionism and psychological adjustment among college students: does educational context matter? North American Journal of Psychology, 13(2).

Hollender, M. H. (1978). Perfectionism, a neglected personality trait. The Journal of Clinical Psychiatry, 39(5), 384-384.

Karabulutlu, Ö. ve Yılmaz, D. (2018). Üniversite öğrencilerinde cinsiyete göre cinsel mitler. Sürekli Tıp Eğitimi Dergisi, 27(3), $155-164$

Karasar, N. (2009). Bilimsel araştırma yöntemi: kavramlarilkeler-teknikler. Ankara: Nobel Yayın Dağıtım.

Karasu, F. ve Sohbet, R. (2019). Opinions of nursing students' about sexual myths. Kadın Sağlığı Hemşireliği Dergisi, 5(2), 2942.

Kilci, Ş. ve Özsoy, S. (2019). Evlilik hazırlığı yapan çiftlerin cinsel mitlere inanma durumları ve etkileyen faktörler. Kadın Sağlı̆̆ı Hemşireliği Dergisi, 5(2), 1-28.

Kiremitci, O., Gençer, T. ve Demiray, E. (2014). Öğretmenlerin mesleğe yönelik davranış ve yaşantı modellerinin çeşitli değişkenlere göre incelenmesi. Eğitim ve Öğretim Araştırmaları Dergisi, 3(2), 66-74.

Kluck, A. S., Zhuzha, K., \& Hughes, K. (2016). Sexual perfectionism in women: Not as simple as adaptive or maladaptive. Archives of Sexual Behavior, 45(8), 2015-2027.

Kukulu, K., Gürsoy, E. ve Sözer, G. A. (2009). Turkish university students' beliefs in sexual myths. Sexuality and Disability, 27(1), 49-59.

Küçüker, B. ve Tekin, U. (2018). 7-8. sinıf özel okul ögrencilerinin sınav kaygısı ile anne-baba tutumları ve mükemmeliyetçi kișilik özellikleri arasındaki ilişkinin incelenmesi. Aydın Sağlık Dergisi, 4(2), 55-68.

Limburg, K., Watson, H. J., Hagger, M. S., \& Egan, S. J. (2017). The relationship between perfectionism and psychopathology: A meta- analysis. Journal of Clinical Psychology, 73(10), 13011326.

McArdle, S. (2010). Exploring domain- specific perfectionism. Journal of Personality, 78(2), 493-508.

Mızrak, Ö. E. (2006). Anksiyete bozukluğu ve/veya depresif bozukluk tanısı alan hastalarda çok boyutlu mükemmeliyetçilik ölçeği uyarlama çalışması (Yayınlanmamış doktora tezi). Ankara Üniversitesi, Ankara.

Miah, M. A. A., Al-Mamun, M. A., Khan, S., \& Mozumder, M. K. (2015). Sexual myths and behavior of male patients with psychosexual dysfunction in bangladesh. Dhaka University Journal of Psychology, 39, 89-100.Oğurlu, Ü., Sevgi-Yalın, H. ve Yavuz-Birben, F. (2015). Üstün yetenekli cocukların mükemmeliyetçilik özelliklerinin aile tutumu ile ilişkisi. Turkish Studies, 10(7), 751-764.

Otrar, M., Dönmez, D. ve Uzel, B. (2018). Orta ergenlik dönemindeki öğrencilerin benlik algılarının mükemmeliyetçilik düzeylerini yordama gücü. HUMANITAS-Uluslararası Sosyal Bilimler Dergisi, 6(12), 235-254.
Özdemir, Ö. ve Yilmaz, M. (2020). Sağllk Profesyonellerinin cinsel mitlere inanma durumlarının belirlenmesi. Adnan Menderes Üniversitesi Sağlık Bilimleri Fakültesi Dergisi, 4(3), 221-232.

Özmen, H. E. (1999). Cinsel mitler ve cinsel işlev bozuklukları (sexual myths and sexual disfunction). Psikiyatri Dünyası, 2, 4953.

Saracaloğlu, A. S., Saygı, C., Yenice, N. ve Altın, M. (2016). Müzik ve sınıf öğretmeni adaylarının mükemmeliyetçilik ve duygusal zekâ düzeylerinin incelenmesi. Mehmet Akif Ersoy Üniversitesi Eğitim Fakültesi Dergisi, 1(38), 70-89.

Satılmış, M. (2010). Öğrencilerin mükemmeliyetçilik tutumları ile anne baba tutumlarının karşılaştırmalı incelenmesi (Yayınlanmamıs yüksek lisans tezi). Selçuk Üniversitesi, Konya.

Selam, G., Erensoy, H. ve Luş, M. G. (2020). Investigation of the relationship between sexual myths and parent attitudes of Turkish women. Nesne, 8(17), 180-188.

Shafran, R., \& Mansell, W. (2001). Perfectionism and psychopathology: A review of research and treatment. Clinical Psychology Review, 21(6), 879-906.

Sheppard, L. A., \& Ely, S. (2008). Breast cancer and sexuality. The Breast Journal, 14(2), 176-181.

Sorkkila, M., \& Aunola, K. (2020). Risk factors for parental burnout among Finnish parents: The role of socially prescribed perfectionism. Journal of Child and Family Studies, 29(3), 648659 .

Stoeber, J., \&Harvey, L. N. (2016). Multidimensional sexual perfectionism and female sexual function: A longitudinal investigation. archives of Sexual Behavior, 45(8), 2003-2014.

Şahbaz, T. (2017). Cinsel mitlerin cinsel işlev bozukluğu ve kaygı üzerine etkisi (Yayınlanmamış yüksek lisans tezi). Iş̣k Üniversitesi, İstanbul.

Torun, F., Torun, S. D. ve Özaydın, A. N. (2011). Men's belief in sexual myths and factors effecting these myths. Düşünen Adam The Journal of Psychiatry and Neurological Sciences, 24, 24-31.

Tuncer, B. ve Voltan-Acar, N. (2006). Kaygı düzeyleri farklı üniversite hazırlık sınıfı öğrencilerinin mükemmeliyetçilik özelliklerinin incelenmesi. Kriz Dergisi, 14(2), 1-15.

Ulu-Kalın, Ö. (2020). Sosyal bilgiler öğretmen adaylarında mükemmeliyetilk. Studies in Educational Research and Development, 41), 1-25.

Uyar-Ekmen, B., Özkan, M. ve Gül, T. (2017). İnfertilite tedavisi gören kadınlarda cinsel mitlere inanma düzeyi. Klinik Psikiyatri Dergisi, 20(3), 209-217.

Uygun, N. ve Kozikoğlu, İ. (2020). Çocukları okul öncesi eğitim kurumlarına devam eden ebeveynlerin tutumlarının incelenmesi. MANAS Sosyal Araştırmalar Dergisi, 9(3), 1494-1507.

Walecka-Matyja, K. (2019). Predictive role of retrospective assessment of parental attitudes of fathers vs. perfectionism and self-esteem of women in early adulthood. Psychatrica Polska, 53(2), 325-339.

World Health Organization. (2015). Sexual health, human rights and the law.

Yılmaz, F. Ö., Erişen, M. A. ve Banaz, M. (2019). Üniversite öğrencilerinin mükemmeliyetçilik düzeylerinin değerlendirilmesi. Journal of Healthcare Management and Leadership, 1, 27-39. 